\title{
Islet autoantibodies in cord blood from children who developed Type I (insulin-dependent) diabetes mellitus before 15 years of age
}

\author{
B. Lindberg ${ }^{1}$, S.-A. Ivarsson ${ }^{1}$, M. Landin-Olsson ${ }^{2}$, G. Sundkvist ${ }^{3}$, L. Svanberg ${ }^{4}$, Å. Lernmark ${ }^{5}$ \\ ${ }^{1}$ Department of Paediatrics, Malmö University Hospital, Malmö, Sweden \\ ${ }^{2}$ Department of Medicine, University of Lund, Lund, Sweden \\ ${ }^{3}$ Department of Endocrinology, Malmö University Hospital, Malmö, Sweden \\ ${ }^{4}$ Department of Obstetrics and Gynaecology, Malmö University Hospital, Malmö, Sweden \\ ${ }^{5}$ Department of Medicine, University of Washington, Seattle, Washington, USA
}

\begin{abstract}
Summary Islet autoantibodies are early markers for Type I (insulin-dependent) diabetes mellitus. The aim of this study was to establish whether islet autoantibodies were present at birth in children who developed Type I diabetes before 15 years of age. Cord blood sera from 81 children who developed Type I diabetes between 10 months and 14.9 years of age were tested for glutamic acid decarboxylase autoantibodies (GAD65Ab), islet cell antigen 512 autoantibodies (ICA512Ab), insulin autoantibodies (IAA) all by quantitative radioligand binding assays and islet cell autoantibodies (ICA) by indirect immunofluorescence. Cord blood sera from 320 randomly selected matched children were controls. The children who developed Type I diabetes had an increased frequency of cord blood islet autoantibodies compared with control subjects: Glutamic acid decarboxylase autoantibodies were detected in $6 \%(5 / 81)$ patients and $2 \%(5 / 320)$ control subjects $(p=0.03)$; islet cell antigen 512 autoantibodies in $5 \%(4 / 73)$ patients and $1 \%(4 / 288)$ control subjects $(p=0.06)$; insulin autoantibodies (IAA) in $0 \%(0 / 79)$ patients and
\end{abstract}

$0.3 \%(1 / 320)$ control subjects $(p=0.36)$; and islet cell autoantibodies in $10 \%(8 / 81)$ patients compared with $0.6 \%(2 / 320)$ control subjects $(p=0.0001)$. Taken together, $17 \%$ (14/81) patients had one or more islet autoantibody compared with $4 \%(12 / 320)$ control subjects $(p=0.0001)$. Whereas none of the control children had more than one antibody, $4 \%$ (3/81) children who later developed Type I diabetes were double positive $(p=0.002)$. Although glutamic acid decarboxylase autoantibodies' concentrations in cordblood correlated to those in the mothers' blood at the time of delivery, no corresponding correlation was found for the other two types of autoantibodies. The increased frequency of cord blood islet autoantibodies suggests that the Type I diabetes process could already be initiated in utero. [Diabetologia (1999) 42: 181-187]

Keywords Autoimmunity, GAD65 antibodies, ICA512 antibodies, insulin autoantibodies, islet cell antibodies.
Received: 20 August 1998 and in revised form: 16 October 1998

Corresponding author: Dr. B. Lindberg, Department of Paediatrics, University of Lund, Malmö University Hospital, S-205 02 Malmö, Sweden.

Abbreviations: GAD65Ab, antibodies to the $65 \mathrm{kDa}$ isoform of glutamate decarboxylase; ICA512Ab, antibodies to the cytoplasmic portion of the ICA512 or IAA-2 protein; IAA, insulin autoantibodies; ICA, islet cell antibodies detected by immunofluorescence on frozen sections; JDF-u, Juvenile Diabetes Foundation units.
Type I (insulin-dependent) diabetes mellitus is a multifactorial disease that develops after exposure to unknown environmental factors in children with specific HLA susceptibility genes. At the time of clinical diagnosis, the majority of the insulin-producing cells in the pancreatic islets have been eradicated in association with autoimmune phenomena including insulitis $[1,2,3]$, lymphocyte proliferation abnormalities [4, $5,6]$ and autoantibodies to islet cell antigens [7-9]. Studies in first-degree relatives [7, 8], twins [9], pregnant mothers $[10,11]$ and school children $[12,13,14]$ have found that islet autoantibodies can be present years before clinical diagnosis. Some [15-17], but not 
all $[9,18-20]$ first-degree relatives who are positive for islet autoantibody markers go on to develop diabetes $[8,15]$. It is therefore speculated that a primary harmful event leads to beta-cell destruction, subsequent antigen presentation and development of islet autoimmunity long before the appearance of hyperglycaemia. Although the detailed mechanisms of the initiating events leading to autoantibody formation are not understood, current approaches to predict Type I diabetes involve the use of cloned autoantigens in standardised radioligand binding assays to detect autoantibodies of high diagnostic sensitivity and specificity (shown in parenthesis as follows). These autoantigens include glutamic acid decarboxylase (GAD65) (75-85\% and 89-99\%, respectively) [21-27], ICA512 (IA-2) (48-56\% and 95-99\%, respectively) [28-30], insulin (28-69\% and 99\%, respectively) [27, 31-33], as well as ICA (80-90\% and 91-97\%, respectively) [33-37]. All radioimmunoassays with recombinant autoantigens are predictive of Type I diabetes and it has been suggested that the combination of GAD65Ab, ICA512Ab and IAA can replace the ICA analysis $[15,38]$.

Recent studies suggest that islet cell autoantibodies can be found at birth in children of mothers who either subsequently develop diabetes [11] or had Type I diabetes during pregnancy $[39,40]$. It has, however, not been determined if islet autoantibodies were present at birth in children who later developed Type I diabetes but were born to healthy mothers. We therefore studied cord blood serum samples that had been stored from more than 60,000 newborn babies $[11,41]$ including $85(0.14 \%)$ children who developed Type I diabetes before they were 15 years of age. Their cord blood serum samples were examined along with the mothers' serum at delivery for GAD65Ab, ICA512Ab, IAA or IA, as well as ICA. The aim of the study was to establish whether islet autoantibodies were present at birth in children who later in life developed Type I diabetes.

\section{Subjects and methods}

Patients. The city of Malmö in Sweden has 240,000 inhabitants who are served by Malmö University Hospital, the only hospital in the entire city. All deliveries take place in the Department of Obstetrics of this hospital. In addition, all children with Type I diabetes are treated at the Department of Pediatrics in the same hospital. From 1969 to 1991, umbilical cord blood samples were obtained from the majority of children born at the hospital, along with samples taken from the mothers at the time of delivery $[11,41]$. Among children born from November 1969 to December $1991(n=61,146)$ and followed until June 1994, there were 106 (0.18\%) who developed Type I diabetes before 15 years of age. A total of 85 of these 106 children had cord blood sera saved at the time of birth (1969-1991). Among the 85 children who developed diabetes, $5 \%(4 / 85)$ had a mother and $10 \%(8 / 83)$ a father with Type I diabetes. The information about heredity from the father was incomplete in two children. Since mothers with Type I diabetes can still be autoantibody positive during pregnancy, the four children who had a mother with Type I diabetes were excluded. All four children had insulin antibodies, two also had GAD65Ab, and one child had ICA512Ab. Three of the four mothers had sera samples saved at delivery, and all three had the same autoantibodies as the children in similar concentrations.

The study comprised 81 children ( 40 male, 41 female) There was enough cord blood to analyse all four islet autoantibodies (ICA, IAA, GAD65Ab, and ICA512Ab) in sera from 73 children, whereas there was only enough sera for ICA, GAD65Ab and IAA from six patients and only enough for ICA and GAD65Ab from two patients. . Sera were also available at delivery from 74 of the 81 mothers. None of the mothers of autoantibody-positive patients have developed Type I diabetes during follow up.

Controls. A total of 320 randomly selected sera (170 male, 150 female) from the bank of cord blood were selected and matched by year of birth to the children who later developed diabetes. There was enough cord blood to analyse all four islet autoantibodies (ICA, IAA, GAD65Ab and ICA512Ab) in sera from 288 children, but only enough sera for ICA, GAD65Ab and IAA analysis in the remaining 32. Information about Type I diabetes among mothers and fathers was not available for the control subjects.

All sera were coded and analysed in the same assay for patients, mothers and control subjects in triplicate. This study was approved by the ethics committee of the Medical Faculty at the University of Lund.

Islet autoantibody assays. We analysed GAD65Ab using a radioligand assay as described previously $[23,26]$. The 320 control cord blood sera were used to define the upper limit of normal using the means +3 SD of the control means. A GAD65Ab index was calculated as described [26]. Our laboratory participated in the international GAD65Ab proficiency test with both sensitivity and specificity of $100 \%$, respectively.

We analysed ICA512Ab in a similar radioligand binding assay as the one described for GAD65Ab [26] using ICA512 cDNA [42] kindly donated by G. Eisenbarth (Denver, Colo., USA) to prepare the ${ }^{35} \mathrm{~S}$-methionine labelled ICA512. The upper limit of normal was defined as for GAD65Ab based on the ICA512Ab index calculated as described[26].

We determined IAA in a competitive binding radioligand assay using monoiodinated insulin as antigen and polyethylene-glycol (PEG) as precipitating agent $[32,31]$. Insulin antibodies were considered present if precipitated radioactivity exceeded non-specific binding and was suppressed by the addition of excess unlabelled insulin. Concentrations of IAA were expressed in $\mathrm{nU} / \mathrm{ml}$ according to an international standard [43]. Values above the means $+3 \mathrm{SD}$ of the control means were considered positive. Our laboratory has participated in the international IAA proficiency programme with both sensitivity and specificity of $100 \%$, respectively.

We analysed ICA with an indirect two-colour immunofluorescence assay $[44,45]$ and the results were expressed in Juvenile Diabetes Foundation units (JDF-u) by a standard curve based on the international JDF-u reference sera sample [46]. The Malmö laboratory participates in the International Diabetes Workshop proficiency programme, and in the 13th evaluation, our ICA assay showed a sensitivity of $100 \%$ and a specificity of $100 \%$.

Statistical Analysis. Comparisons between groups were done with Fishers' exact test (two-tailed), nonparametric statistics 
Table 1. Islet autoantibodies in cord blood, sex and the age at diagnosis in children who developed Type I diabetes before 15 years of age

\begin{tabular}{lrlll}
\hline & $n$ & $\begin{array}{l}\text { Male/ } \\
\text { Female }\end{array}$ & \multicolumn{2}{c}{$\begin{array}{l}\text { Age at diagnosis } \\
\text { (years) }\end{array}$} \\
\cline { 4 - 5 } & & & Median & Range \\
\hline Islet autoantibody & & $3 / 2$ & 10.6 & $5.3-14$ \\
GAD65Ab & 5 & $1 / 3$ & 9.4 & $6.5-11.9$ \\
ICA512Ab & 4 & $4 / 4$ & 9.2 & $3.3-13.1$ \\
ICA & 8 & $64 / 33$ & 8.7 & $0.9-14.9$ \\
Antibody negative & 67 & 34 & 8.4 & $0.9-14.9$ \\
All & 81 & $40 / 41$ & &
\end{tabular}

were done by Mann-Whitney U-test. Correlations were calculated using StatWiew 4.5 software (Abacus Concepts, Berkely, USA).

\section{Results}

The data shows that the age at diagnosis of Type I diabetes ranged from 10 months to 14.9 years (median 8.4 years; Table 1 ). There was an increased frequency of islet autoantibodies in the cord blood among the 81 children who developed Type I diabetes compared with the 320 control subjects (Tables 1 and 2). There was no significant difference in sex or age at diagnosis of Type I diabetes between patients with islet autoantibodies and those without autoantibodies at birth (Table 1). At least one islet autoantibody was detected in $17 \%(14 / 81)$ of the children who later developed Type I diabetes, compared with $4 \%(12 / 320)$ control subjects $(p=0.0001)$. These data suggest that islet autoantibodies are already common at birth in children who later in life develop Type I diabetes. We next investigated whether any individual type of islet autoantibodies was more prevalent than the others (Table 2). We also analysed the presence of autoantibodies in cord blood compared with the mothers' autoantibodies at the time of delivery (Table 3 ). For time clustering, the season of birth and antibody positivity was also analysed (Table 4).

We found GAD65Ab in 6\% $(5 / 81)$ of patients (mean 0.46 GAD65Ab index; range 0.14-1.19) compared with $2 \%(5 / 320)$ among the control subjects $(p=0.03$ ) $0.11-0.78$ (mean 0.26 GAD65Ab index, range). Sera were available from $4 / 5$ mothers of later diabetic children: two had GAD65Ab at concentrations similar to those of their offspring and a positive correlation was found between the GAD65Ab concentrations in child and mother $(r=$ $0.825, p<0.0001)$. Patients positive for GAD65Ab were more often born in the spring (March-May) than during the rest of the year, compared with the GAD65Ab negative subjects $(p=0.03$; Table 4$)$.

We detected ICA512Ab in 5\% (4/73) of patients (mean 0.03 ICA512Ab index; range 0.02-0.04) and $(1 \%)(4 / 288)$ control subjects (mean 0.02 ICA512Ab index; range 0.02-0.04) $(p=0.06)$. Among the ICA512Ab positive children who later developed diabetes, all mothers were ICA512Ab negative, thus no correlation was found between ICA512Ab concentrations in cordblood compared with the mothers' blood $(r=0.15, p=0.21)$.

Insulin autoantibodies (IAA) were not found in any of the children who later developed diabetes compared with IAA in $0.3 \%(1 / 320)$ among the control subjects $(p=0.36)$.

Cord blood ICA were detected in $10 \%(8 / 81)$ of children who later developed diabetes (mean 5.9 JDF-u; range 3-20) compared with $0.6 \%$ (2/320) $(p=0.0001)$ in the control group (mean 5.0 JDF-u; range 4-6). None of the seven mothers with available sera had ICA, even though the child was ICA positive. No correlation was found between ICA concentrations in cord blood compared with the mothers' blood ( $r=0.05, p=0.67$ ). Patients positive for ICA were more often born in the autumn (September-November) than during the rest of the year, compared with ICA negative subjects ( $p=0.04$; Table 4$)$.

Whereas none of the control children had more than one antibody, $4 \%$ (3/81) children who later de-

Table 2. Islet autoantibodies in cord blood among children later developing Type I diabetes and in matched control subjects

\begin{tabular}{|c|c|c|c|c|c|c|}
\hline \multirow[b]{2}{*}{$\begin{array}{l}\text { Patients } \\
\text { Control subjects }\end{array}$} & \multirow{2}{*}{$\begin{array}{l}\text { GAD65Ab } \\
n=81 \\
n=320\end{array}$} & \multirow{2}{*}{$\begin{array}{l}\text { ICA512Ab } \\
n=73 \\
n=288\end{array}$} & \multirow{2}{*}{$\begin{array}{l}\text { IA } \\
n=79 \\
n=320\end{array}$} & \multirow{2}{*}{$\begin{array}{l}\text { ICA } \\
n=81 \\
n=320\end{array}$} & \multicolumn{2}{|l|}{ Number } \\
\hline & & & & & patients & control subjects \\
\hline & + & - & - & - & 3 & 5 \\
\hline & - & + & - & - & 3 & 4 \\
\hline & - & - & + & - & 0 & 1 \\
\hline & - & - & - & + & 4 & 2 \\
\hline & - & $\mathrm{m}$ & - & + & 1 & 0 \\
\hline & + & - & - & + & 1 & 0 \\
\hline & + & $\mathrm{m}$ & $\mathrm{m}$ & + & 1 & 0 \\
\hline & - & + & - & + & 1 & 0 \\
\hline Total Positive & & & & & $14(17 \%)$ & $12(4 \%)$ \\
\hline Total Negative & - & - or $\mathrm{m}$ & - or $\mathrm{m}$ & - & $67(79 \%)$ & $308(96 \%)$ \\
\hline
\end{tabular}

$\mathrm{m}=$ missing samples 
Table 3. Comparison of islet autoantibodies between positive cord blood serum and mothers serum at the time of delivery

\begin{tabular}{|c|c|c|c|c|c|c|c|}
\hline \multirow[t]{3}{*}{$\mathrm{Ab}$ (unit) } & \multirow{3}{*}{$\begin{array}{l}\text { Total } \\
n\end{array}$} & \multicolumn{3}{|c|}{ Concordant } & \multicolumn{3}{|c|}{ Discordant } \\
\hline & & \multirow[t]{2}{*}{$n$} & \multicolumn{2}{|l|}{ Ab-levels } & \multirow[t]{2}{*}{$\bar{n}$} & \multicolumn{2}{|l|}{ Ab-levels } \\
\hline & & & child & mother & & child & mother \\
\hline GAD65Ab (index) & 4 & 2 & $0.16-0.53$ & $0.18-0.40$ & 2 & $0.14-0.21$ & $0.01-0.09$ \\
\hline ICA512Ab (index) & 4 & 0 & 0 & 0 & 4 & $0.02-0.04$ & $0.00-0.01$ \\
\hline ICA (JDF) & 7 & 0 & 0 & 0 & 7 & $3-20$ & 0 \\
\hline Total (samples) & 15 & 2 & & & 13 & & \\
\hline Total (children) & 13 & 2 & & & 11 & & \\
\hline
\end{tabular}

Newborns with venous blood missing from mother are excluded

Table 4. Season of birth for children with different islet autoantibodies

\begin{tabular}{lllll}
\hline $\begin{array}{l}\text { Time } \\
\text { of birth }\end{array}$ & $\begin{array}{l}\text { Winter } \\
\text { (Dec-Feb) }\end{array}$ & $\begin{array}{l}\text { Spring } \\
\text { (Mar-May) }\end{array}$ & $\begin{array}{l}\text { Summer } \\
\text { (Jun-Aug) }\end{array}$ & $\begin{array}{l}\text { Autumn } \\
\text { (Sep-Nov) }\end{array}$ \\
\hline $\begin{array}{l}\text { all }(n) \\
\begin{array}{l}\text { GAD65Ab } \\
\text { positive }\end{array}\end{array}$ & 14 & 25 & 19 & 23 \\
$\begin{array}{l}\text { ICA512Ab } \\
\text { positive }\end{array}$ & 0 & $4^{\mathrm{a}}$ & 1 & 0 \\
$\begin{array}{l}\text { ICA } \\
\text { Any Ab }\end{array}$ & 1 & 0 & 2 & 2 \\
positive & 1 & 2 & 0 & $5^{\mathrm{a}}$ \\
\hline
\end{tabular}

a denote clustering with $p<0.05$

veloped Type I diabetes were double positive $(p=0.002)$. Both ICA and GAD65Ab were found in two children who developed Type I diabetes at the ages of 10.5 years and 12.8 years, respectively. One child with a combination of ICA and ICA $512 \mathrm{Ab}$ was 11.9 years old at diagnosis. Other combinations were not detected. Among control subjects, no child had more than one autoantibody.

The mean age at delivery of the mothers of children with antibodies, who later developed diabetes, was 28.9 years (18-40 years) compared with 27.3 (18-42 years) for the mothers of children without antibodies $(p=\mathrm{NS})$.

\section{Discussion}

This investigation was possible because sera had been saved from the majority of children born in the city of Malmö since 1969. Cord blood from 81 children who developed Type I diabetes before 15 years of age were analysed and $17 \%(14 / 81)$ had at least one islet autoantibody when born. Our study shows that children who develop Type I diabetes have an increased prevalence of cord blood islet autoantibodies compared with control subjects.

It is well known that GAD65Ab, ICA512Ab, IAA or ICA, alone or in combination, predict Type I diabetes in first-degree relatives $[8,37,47]$. The positive predicted value after 3 and 5 years follow-up, respec- tively, is estimated for GAD65Ab to be $28 \%$ and $52 \%$, respectively; for ICA $512 \mathrm{Ab} 40 \%$ and $81 \%$, respectively; for IAA $33 \%$ and $59 \%$, respectively; and for ICA ( > $20 \mathrm{JDF}-\mathrm{u}$ ) $31 \%$ and $51 \%$, respectively. Among relatives with two or more of these autoantibodies, the risk of Type I diabetes within 3 years was $39 \%$, and within 5 years $68 \%$ (if they had ICA $>20$ JDF-u), and with all three autoantibodies and ICA $>20 \mathrm{JDF}-\mathrm{u}$, the risk for Type I diabetes within 5 years is estimated to be $100 \%$ [15]. In our study there were $10 \%(8 / 83)$ fathers and $5 \%(4 / 85)$ mothers with Type I diabetes. Diabetes in the family was therefore not a prerequisite for cord blood positivity. In future attempts to prevent Type I diabetes in the general population, it will be necessary to determine the positive predictive value following autoantibody screening of newborn babies. Such studies are underway [48].

The cord blood autoantibodies could come from the mother since the fetus has a minor production of $\mathrm{IgG}$ and transport of $\mathrm{IgG}$ over the placenta barrier is an active process giving the newborn baby an $\mathrm{IgG}$ concentration of $150 \%$ of the mother's [49]. Two examples of diseases in the newborn caused by placental transfer of autoantibodies are thrombocytopenia in children born to mothers with autoantibodies against platelets [50] and neonatal thyrotoxicosis [51] caused by transfer of thyrotropin receptor-stimulating autoantibodies. We have shown earlier that mothers who at some time after pregnancy developed Type I diabetes had transplacentally transferred ICA and GAD autoantibodies to their children [11]. This has also been reported for IAA and GAD65Ab [39, $40,52]$ and for ICA512Ab [39]. Our study indicates that transplacental passage could differ between islet autoantibodies.

Our study showed IAA was not found in cord blood from any of the later diabetic children included in our series. Four children of mothers with Type I diabetes (excluded from our series because of this), however, had insulin antibodies, two had also GAD65Ab and one ICA512Ab, all at similar concentrations to their mothers in line with the BABYDIAB study [53].

The correlation found for GAD65Ab between child and mother, indicates that the main reason for 
cord blood autoantibodies was transplacental passage. The possibility of fetal-produced autoantibodies is not completely excluded, however. An earlier study implicated fetal-produced antibodies when one of the infants with antibody-positivity at birth continued to be IAA positive at follow-up at 2 years of age [52]. In this study we show that ICA512Ab and ICA only occurred in cord blood and not in the mother. This suggests that these autoantibodies were produced by the fetus. Concordant with this is our observation that the ICA antigen is present in the fetal pancreas which suggests autoimmune reactions against beta cells in utero [54]. It has been reported that ICA512Ab, in contrast to GAD65Ab, are closely associated with Type I diabetes developing before puberty $[42,55,56]$. We speculate therefore that prepubertal diabetes could often be a consequence of intrauterine induced autoimmunity.

The cord-blood autoantibody-positive children in our study did not, however, have an earlier clinical onset of Type I diabetes compared with the antibody-negative children. Intrauterine factors could still have an important role. This is suggested by the findings that congenital rubella is associated with a greatly increased risk of Type I diabetes $10-30$ years after the intrauterine infection $[57,58]$. Recently, we [59] and others [60] have shown that other viral infections, such as Coxsackie and Echo, during pregnancy increase the risk of Type I diabetes in childhood and adolescence. Possible mechanisms leading to autoantibody formation in congenital infections are viral epitopes sharing determinants with beta cell epitopes resulting in a cross reaction with beta cells $[61,62]$ or direct damage to the beta cells leading to exposure of normally hidden antigens. The seasonal pattern with higher prevalence than expected of GAD65Ab positivity among children born in the spring and ICA positivity among children born in the autumn could also imply a role for infections.

In conclusion, islet autoantibodies are present at birth more frequently than expected in children who later develop Type I diabetes which suggests that beta cell damage can start in utero. The importance of this is twofold. Firstly, such early beta cell damage underscores the importance of devising safe forms of immunological intervention that can permanently halt damage. Secondly, screening for islet autoantibodies at birth could be a crucial step in identifying those at risk of developing Type I diabetes. Thus, the question is: should early intervention and screening start at birth?

Acknowledgements. This study was supported by grants from the Medical Faculty, University of Lund, the Health Services Administration, Malmö; the Novo Nordisk Foundation; the Malmö Branch of the Swedish Diabetic Association; the Swedish Child Diabetes Foundation; the Lions Club International District 101-S; the Hoechst Diabetes Foundation; the TryggHansa Research Fund; The Sven Jerring Foundation; the
Swedish Medical Research Council (27X-12274); and the National Institutes of Health (DK26190).

\section{References}

1. Gepts W (1965) Pathologic anatomy of the pancreas in juvenile diabetes mellius. Diabetes 14: 613-633

2. Bottazzo GF, Dean BM, McNally JM, Mac Kay EH, Swift PGF, Gamble DR (1985) In situ characterization of autoimmune phenomena and expression of HLA molecules in the pancreas in diabetic insulinitis. N Engl J Med 313: 353-360

3. Lernmark Å, Klöppel G, Stenger D et al. (1995) Heterogeneity of human islet pathology in newly diagnosed childhood insulin-dependent diabetes mellitus. Macrophage infiltrations and expression of HLA-DQ and glutamic acid decarboxylase. Virchows Arch 425: 631-640

4. Roep B, Kallan A, Hazenbos W et al. (1991) T-cell reactivity to $38 \mathrm{kD}$ insulin-secretory-granule protein in patients with recent-onset type 1 diabetes. Lancet 337: 1439-1441

5. Atkinson M, Bowman M, Campbell L, Darrow B, Kaufman D, Maclaren N (1994) Cellular immunity to a determinant common to glutamate decarboxylase and coxsackie virus in insulin-dependent diabetes. J Clin Invest 94: 2125-2129

6. Honeyman M, Stone N, de Aizpurua H, Rowley M, Harrison L (1997) High T-cell responses to the glutamic acid decarboxylase (GAD) isoform 67 reflect a hyperimmune state that precedes the onset of insulin-dependent diabetes. J Autoimmunity 10: 165-173

7. Riley WJ, Maclaren NK, Krischer J et al. (1990) A prospective study of the development of diabetes in relatives of patients with insulin-dependent diabetes. N Engl J Med 323: $1167-1172$

8. Bingley PJ, Christie MR, Bonifacio E et al. (1994) Combined analysis of autoantibodies improves prediction of IDDM in islet cell antibody-positive relatives. Diabetes 43: $1304-1310$

9. Verge C, Gianani R, Yu L et al. (1995) Late progression to diabetes and evidence for chronic beta-cell autoimmunity in identical twins of patients with type 1 diabetes. Diabetes 55: $1176-1179$

10. Tuomilehto J, Zimmet P, Mackay I et al. (1994) Antibodies to glutamic acid decarboxylase as predictors of insulin-dependent diabetes mellitus before clinical onset of disease. Lancet 343: 1383-1385

11. Ivarsson SA, Ackefors M, Carlsson A et al. (1997) Glutamate decarboxylase antibodies in non-diabetic pregnancies precedes insulin-dependent diabetes in the mother but not necessarily in the offspring. Autoimmunity 26: 261-269

12. Landin-Olsson M, Karlsson A, Dahlquist G, Blom L, Lernmark $\AA$, Sundkvist G (1989) Islet cell and other organspecific autoantibodies in all children developing type 1 (insulin-dependent) diabetes mellitus in Sweden during one year and in matched controls. Diabetologia 32: 387-395

13. Levy-Marchal C, Tichet J, Fajardy I, Gu XF, Dubois F, Czernichow P (1992) Islet cell antibodies in normal French school-children. Diabetologia 35: 577-582

14. Schatz D, Krischer J, Horne G et al. (1994) Islet cell antibodies predict insulin-dependent diabetes in United States school age children as powerful as in unaffected relatives. J Clin Invest 93: 2403-2407

15. Verge CF, Gianani R, Kawasaki E et al. (1996) Prediction of type I diabetes in first-degree relatives using a combina- 
tion of insulin, GAD, and ICA512bdc/IA-2 autoantibodies. Diabetes 45: 926-933

16. Cantor A, Krischer J, Cuthbertson DD et al. (1995) Age and family relationship accentuate the risk of insulin-dependent diabetes mellitus (IDDM) in relatives of patients with IDDM. J Clin Endocrinol Metab 80: 3739-3743

17. Bingley P (1996) Interactions of age, islet cell antibodies, insulin antibodies, and first-phase insulin response in predicting risk of progression to IDDM in ICA( $(+)$ relatives: The ICARUS data set. Diabetes 45: 1720-1728

18. McCulloch D, Klaff L, Kahn S et al. (1990) Nonprogression of subclinical beta-cell dysfunction among first degree relatives of IDDM patients: 5- yr. follow-up of the Seattle family study. Diabetes 39: 549-556

19. Bärmeier H, McCulloch D, Neifing J et al. (1991) Risk for developing type 1 (insulin-dependent) diabetes mellitus and the presence of islet $64 \mathrm{~K}$ antibodies. Diabetologia 34: 727-733

20. Yu L, Gianani R, Eisenbarth G (1994) Quantitation of glutamic acid decarboxylase autoantibody levels in prospectively evaluated relatives of patients with type 1 diabetes. Diabetes 43: 1229-1233

21. Baekkeskov S, Nielsen JH, Marner B, Bilde T, Ludvigsson J, Lernmark A (1982) Autoantibodies in newly diagnosed diabetic children immunoprecipitate human pancreatic islet cell proteins. Nature 298: 167-169

22. Baekkeskov S, Aanstoot H-K, Christgau S et al. (1990) Identification of the $64 \mathrm{k}$ autoantigen in insulin-dependent diabetes as the GABA-synthesizing enzyme glutamic acid decarboxylase. Nature 347: 151-156

23. Grubin CE, Daniels T, Toivola B et al. (1994) A novel radioligand binding assay to determine diagnostic accuracy of isoform-specific glutamic acid decarboxylase antibodies in childhood IDDM. Diabetologia 37: 344-350

24. Schmidli RS, Colman PG, Bonnifacio E (1995) Disease sensitivity and specificity of 52 assays for glutamic acid decarboxylase antibodies. The Second International Glutamic Acid Decarboxylase Workshop. Diabetes 44: 636-640

25. Vandevalle C, Falorni A, Svanholm S, Lernmark Å, Pipeleers D, Gorus F (1995) High diagnostic sensitivity of glutamate decarboxylase autoantibodies in insulin-dependent diabetes mellitus with clinical onset between age 20 and 40 years. The Belgian Diabetes Registry. J Clin Endocrinol Metab 80: 846-851

26. Falorni A, Örtqvist E, Persson B, Lernmark $\AA$ (1995) Radioimmunoassays for glutamic acid decarboxylase (GAD65) and GAD65 autoantibodies using ${ }^{35} \mathrm{~S}$ or ${ }^{3} \mathrm{H}$ recombinant human ligands. J Immunol Methods 186: 89-99

27. Hagopian W, Sanjeevi C, Kockum I et al. (1995) Glutamate decarboxylase-, insulin- and islet cell antibodies and HLA typing to detect diabetes in a general population-based study of Swedish children. J Clin Invest 95: 1505-1511

28. Lan M, Lu J, Goto Y, Notkins A (1994) Molecular cloning and identification of a receptor-type protein tyrosine phosphatase, IA-2, from human insulinoma. DNA Cell Biol 13: 505-514

29. Payton MA, Hawkes CJ, Christie MR (1995) Relationship of the 37,000- and 40,000-Mr tryptic fragments of islet antigens in insulin-dependent diabetes to the protein tyrosine phosphatase-like molecule IA-2 (ICA512). J Clin Invest 96: $1506-1511$

30. Rabin DU, Pleasic SM, Shapiro JA et al. (1994) Islet cell antigen 512 is a diabetes-specific islet autoantigen related to protein tyrosine phosphatases. J Immunol 152: 3183-3187

31. Greenbaum C, Palmer J, Kuglin B, Kolb H (1992) Insulin autoantibodies measured by radioimmunoassay methodol- ogy are more related to insulin-dependent diabetes mellitus than those measured by enzyme-linked immunosorbent assay: Results of the Fourth International Workshop on the Standardization of Insulin Autoantibody measurement. J Clin Endocrinol Metab 74: 1040-1044

32. Palmer JP, Asplin CM, Clemons P et al. (1983) Insulin antibodies in insulin-dependent diabetics before insulin treatment. Science 222: 1337-1339

33. Landin-Olsson M, Palmer J, Lernmark Å et al. (1992) Predictive value of islet cell and insulin autoantibodies for type 1 (insulin-dependent) diabetes mellitus in a population-based study of newly-diagnosed diabetic and matched control children. Diabetologia 35: 1068-1073

34. Lernmark $\AA$ (1987) Islet cell antibodies-theoretical and practical implications. Diabetic Medicine 4: 285-292

35. Greenbaum CJ, Palmer JP, Nagataki S et al. (1992) Improved specificity of ICA assays in the fourth international immunology of diabetes serum exchange workshop. Diabetes 42: $1570-1574$

36. Lendrum R, Walker G, Cudworth AG et al. (1976) Islet cell antibodies in diabetes mellitus. Lancet ii: 1273-1276

37. Bonifacio E, Genovese S, Braghi S et al. (1995) Islet autoantibody markers in IDDM: risk assessment strategies yielding high sensitivity. Diabetologia 38: 816-822

38. Wiest-Ladenburger U, Hartmann R, Hartmann U, Berling K, Böhm B, Richter W (1997) Combined analysis and single-step detection of GAD65 and IA2 autoantibodies in IDDM can replace the histochemical islet cell antibody test. Diabetes 46: 565-571

39. Roll U, Christie M, Standl E, Ziegler AG (1994) Association of anti-GAD antibodies with islet cell antibodies and insulin autoantibodies in first-degree relatives of type 1 diabetic patients. Diabetes 43: 154-160

40. Martikainen A, Saukkonen T, Kulmala PK et al. (1996) Disease-associated antibodies in offspring of mothers with IDDM. Diabetes 45: 1706-1710

41. Ahlfors K, Ivarsson S-A, Johnsson I, Svanberg I (1982) Primary and secondary maternal cytomegalovirus infections and their relation to congenital infection. Acta Paediatr Scand 71: 109-113

42. Kawasaki E, Yu L, Gianani R et al. (1997) Evaluation of islet cell antigen (ICA) 512/IA-2 autoantibody radioassays using overlapping ICA512/IA-2 constructs. J Clin Endocrino Metab 82: 375-380

43. Palmer JP, Wilkin TJ, Kurtz AB, Bonifacio E (1990) The third international workshop on the standardization of insulin antibody measurement. Diabetologia 33: 60-61

44. Landin-Olsson M, Sundkvist G, Lernmark $\AA$ (1987) Prolonged incubation in the two-colour immunofluorescence test increases the prevalence and titres of islet cell antibodies in Type 1 (insulin-dependent) diabetes mellitus. Diabetologia 30: 327-332

45. Madsen OD, Landin-Olsson M, Bille G et al. (1986) A twocolour immunofluorescence test with a monoclonal human proinsulin antibody improves the assay for islet cell antibodies. Diabetologia 29: 115-118

46. Bonifacio E, Lernmark $\AA$, Dawkins et al. (1988) Serum exchange and use of dilutions have improved precision of measurement of islet cell antibodies. J Immunol Methods 106: $83-88$

47. Gorsuch AN, Spencer KM, Lister J et al. (1981) Evidence for a long prediabetic period in Type 1 (insulin-dependent) diabetes mellitus. Lancet 26: 1363-1364

48. Norris J, Beaty B, Klingensmith G et al. (1996) Lack of association between early exposure to cow's milk protein and beta-cell autoimmunity. Diabetes Autoimmunity Study in the Young (DAISY). JAMA 276: 609-614 
49. Hayward AR (1981) Development of immunity mechanism. In: Soothill JF, Hayward AR, Wood CBS (eds.) Paediatric Immunology. Blackwell scientific publications Oxford, pp 48-55

50. McIntosh S, Pearson HA (1973) Isoimmune neonatal purpura. J Pediatr 82: 1020

51. Hollingsworth DR (1985) Neonatal hyperthyroidism. In: Delange F, Fisher DA, Malvaux P (eds.) Pediatric thyroidology. Karger Basel, New York, pp 210-222

52. Ziegler AG, Hillebrand B, Rabl W et al. (1993) On the appearance of islet associated autoimmunity in offspring of diabetic mothers: a prospective study from birth. Diabetologia 36: 402-408

53. Roll U, Christie MR, Fuchtenbusch M, Payton MA, Hawkes CJ, Ziegler AG (1996) Perinatal autoimmunity in offspring of diabetic parents. The German Multicenter BABY-DIAB study: detection of humoral immune responses to islet antigens in early childhood. Diabetes 45: 967-973

54. Sundkvist G, Bergqvist A, Weibull H et al. (1991) Islet cell antibody reactivity with human fetal pancreatic islets. Diabetes Res Clin Pract 14: 1-8

55. Yokota I, Matsuda J, Naito E, Ito M, Shima K, Kuroda Y (1998) Comparison of GAD and ICA512/IA-2 antibodies at and after the onset of IDDM. Diabetes Care 21: 49-52
56. Genovese S, Bonfanti R, Bazzigaluppiu E et al. (1996) Association of IA-2 autoantibodies with HLA DR4 phenotypes in IDDM. Diabetologia 39: 1223-1226

57. Forrest JM, Menser MA, Burgess JA (1971) High frequency of diabetes mellitus in young adults with congenital rubella. Lancet ii: $332-334$

58. Ginsberg-Fellner F, Witt ME, Fedun B et al. (1985) Diabetes mellitus and autoimmunity in patients with congenital rubella syndrome. Rev Infect Dis 7 [Suppl 1]: 170-176

59. Dahlquist G, Ivarsson S, Lindberg B, Forsgren M (1995) Maternal enteroviral infection during pregnancy as a risk factor for childhood IDDM. Diabetes 44: 408-413

60. Hyöty H, Hiltunen M, Knip M et al. (1995) A prospective study of the role of coxsackie B and other enterovirus infections in the pathogenesis of IDDM. Childhood Diabetes in Finland (DiMe) Study. Diabetes 44: 652-657

61. Oldstone MBA (1987) Molecular mimicry and autoimmune disease. Cell 50: 819-820

62. Kaufman D, Erlander M, Clare-Salzler M, Atkinson M, Maclaren N, Tobin A (1992) Autoimmunity to two forms of glutamate decarboxylase in insulin-dependent diabetes mellitus. J Clin Invest 89: 283-292 